\title{
Exclusionary inclusion and inclusive exclusion: studies on harassment at a members club
}

\author{
Fernando Ressetti Pinheiro Marques Vianna ${ }^{1}$ \\ FRANCIS KaNASHIRO MENEGHETtI ${ }^{2}$ \\ Juliana PREViatto Baltini TONON ${ }^{3}$ \\ LEONARDO TONON ${ }^{2}$ \\ ${ }^{1}$ Fundação Getulio Vargas (FGV EAESP) / SÃo PAUlo SCHOOl of BusinesS AdMINISTRATION, SÃo PAUlo - SP, BRAZIL

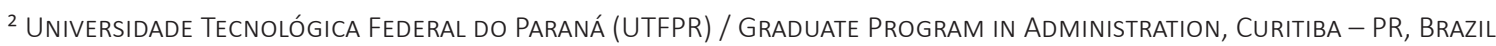 \\ ${ }^{3}$ FACULdAdE DE CIÊNCIAS SOCIAIS E APLICADAS Do PARANÁ (FACET), CURITIBA - PR, BRAZIL
}

\begin{abstract}
This article was motivated by situations of social exclusion of certain groups at a members club in southern Brazil. Through an ethnographic study, we sought to analyze how marginalized populations are socially excluded from certain situations and included in others, and why. Social situations are often symbolic, such as the wearing of uniforms, the existence of a "senzala" for employees, the non-relationship between members and employees, among others, allowed us to explore the dialectical movement between exclusion and inclusion. It is in this context that inclusive exclusion and exclusionary inclusion are discussed. This process results in the maintenance of social inequality through seemingly normal, justifiable, institutionally accepted, and encouraged practices. For marginalized populations included and / or excluded through these practices, the consequences are the reproduction and legitimation of this precarious condition.
\end{abstract}

Keywords: Inclusive exclusion. Exclusionary inclusion. Social club. Ethnography.

\section{Inclusão excludente e exclusão includente: estudos sobre a ralé em um clube social}

\section{Resumo}

Este artigo foi motivado por situações de exclusão social de determinados grupos em um clube social no Sul do Brasil. Por meio de estudo etnográfico, buscou-se analisar de que modo a ralé é socialmente excluída de determinadas situações e incluída em outras e por qual motivo. Situações sociais, muitas vezes de ordem simbólica, como o uso de uniformes, a existência de uma "senzala" para os funcionários e a não relação entre sócios e funcionários, entre outras, possibilitaram que o movimento dialético entre o excluir e o incluir fosse explorado. É nesse contexto que se discute a exclusão includente e a inclusão excludente. Tal processo resulta na manutenção da desigualdade social por meio de práticas aparentemente normais, justificáveis, institucionalmente aceitas e incentivadas. Para a ralé, porém, que é incluída e/ou excluída por meio dessas práticas, as consequências são a reprodução e a legitimação de sua condição de precariedade.

Palavras-chave: Inclusão excludente. Exclusão includente. Clube social. Etnografia.

\section{Inclusión excluyente y exclusión incluyente: estudios sobre la clase baja en un club social}

\section{Resumen}

Este artículo fue motivado por situaciones de exclusión social de ciertos grupos en un club social en el sur de Brasil. A través de un estudio etnográfico, buscamos analizar cómo la clase baja es socialmente excluida de ciertas situaciones e incluida en otras, y por qué motivo. Las situaciones sociales, a menudo simbólicas, como el uso de uniformes, la existencia de "dependencias de empleados", la no relación entre socios y empleados, entre otros, nos permitieron explorar el movimiento dialéctico entre excluir e incluir. En este contexto discutimos la exclusión incluyente y la inclusión excluyente. Este proceso resulta en el mantenimiento de la desigualdad social a través de prácticas aparentemente normales, justificables, institucionalmente aceptadas y alentadas. Sin embargo, para la clase baja, que es incluida y/o excluida a través de estas prácticas, las consecuencias son la reproducción y legitimación de su condición precaria.

Palabras clave: Inclusión excluyente. Exclusión incluyente. Club social. Etnografía. 


\section{INTRODUCTION}

One of you stole my daughter's boot!

This epigraph was the statement that motivated the writing of this article - it was spoken at a June country party at a social club in southern Brazil and directed at a member of the party's security staff. Instead of reacting to this accusation, the security guard quickly left in search of the stolen item.

The security guard can be classified as a member of the ralé or "rabble" (SOUZA, 2017), a class descended from the slavery tradition in Brazil. This class is the fruit of the abandonment of ex-slaves and legitimized by the argument that blames corruption and the State for their situation, but excludes the upper and middle classes from responsibility. Souza (2017) states that the rabble is not related to any economic classification, but rather its apparatus to compete in the world. The social inequality demonstrated by the existence of this social inequality, which Freitas and Luna (2006) affirm is a problem that needs to be faced by Brazilian society, does not appear to be a problem to the contemporary oppressors of the middle class (SOUZA, 2017).

When the party guest mentioned in the first paragraph accuses the security guard, she is legitimizing the social inequality in which members of this class are affected socially, culturally and economically as well as in various other spheres. The security guard legitimizes the inequality with which he's treated when he does not react to the accusation, because the hegemonic discourse of meritocracy always points to the fact that his being there is a form of inclusion, an "opportunity" to not become a delinquent. This situation demonstrates the problem of inequality in including the security guard in a class of non-entities (MACIEL and GRILLO, 2009). This rabble class cannot dream of being doctors or professors; it is rather understood that its members should focus on not being criminals.

Evidence of the exclusion of the rabble can be identified in other publications, such as the journalistic reports of Boere and Lima (2016) and Martín (2016), which explore this subject through the lenses of the prejudice and humiliation suffered by nannies in an elite club in Rio de Janeiro. These women cannot even use the women's bathroom, because "they don't have the same education" as the members, according to a member of the club (BOERE and LIMA, 2016).

Based on these situations, an empirical one experienced by one of the authors in a club party and the other related in consulted reports, we seek to question:

- In what way is the rabble socially excluded in certain situations and included in others?

- What motives lead to these forms of exclusion and/or inclusion?

Even though various studies address social exclusion in certain groups (MEDEIROS and MACÊDO, 2006; SOUZA, 2009; CARVALHOFREITAS and MARQUES, 2010), this article justifies its development on exploring the movement between exclusion and inclusion as a process which results in the maintenance of social inequality. The development of work in an elite club makes the study richer from the empirical point of view. This is because it presents the exclusion/inclusion dialectic in apparently normal, justified practices which are institutionally accepted and encouraged. Despite these characteristics, on the other hand, what is included and/or excluded through these practices reproduces and legitimizes this precarious condition which has existed since colonial times.

In terms of the relationship of this article with organizational studies, we first address the fact that they are permeated by other areas of research such as sociology, psychology and anthropology (MATITZ and VIZEU, 2012). Then, we consider how the aspects exposed here relative to the ways in which the organization expresses its management are removed from modern justifications and present points similar to the construction of organizational studies in Brazil (PAULA, MARANHÃO, BARRETO et al., 2010; DJELIC, 2016).

Within the area in question, social exclusion has been the subject of important works relative to cities and spaces (GONÇALVES, PAIVA, BARBOSA et al., 2009; BENTO, ROJAS, LEMOS et al., 2016; SILVA, LIMA and NELSON, 2016), but this study explores another perspective with the help of sociology. The recent works of Jessé de Souza and the consecrated works of José de Souza Martins are used here in an unprecedented manner in organizational and administration studies with the objective of presenting a group (or combination) of management practices which reaffirm the exclusion that has existed in Brazil from its inception and are removed from purely economic issues (MARTINS, 1997). 
Thus, to explore more situations such as the one related in the first paragraph of this article, our object of study will be the social situations generated by interactions between club members and employees in a middle class club in southern Brazil.

According to the guidelines of Spradley (2016) for the development of ethnographic studies, the observation of social situations is performed through accompanying activities that generate these situations. Thus, the observations occur mainly in the club's gym, but are also amplified at times with other activities which constitute opportunities to deepen our research, such as environments of recreation, dining, and other events in the club. During the study, some of the employees engaged in informal conversations, which were rich in information.

The study was conducted between August and December 2018. The average frequency of observations was 4 times per week, for at least one hour per day, at different times. The notations were made on the word pad of a cell phone. The choice of a smartphone was made to maintain a certain anonymity to the extent that the use of these devices is common among club members, avoiding calling attention to the researcher and making it viable to take notes in real time. Later, the notes were transcribed in the form of field diaries, making it possible to perform some analyses developed during the progression of the study itself.

During the study, we were able to enter into contact with various club employees of different hierarchical levels as well as observe their functions and relationships with the clients and among themselves. There were many conversations of short or medium duration as the study progressed. These conversations enriched the observations, because in the observed interactions, that which was related or informed was corroborated or contradicted.

During these conversations and observations, a closer proximity was established with one of the workers. Thus, the main participant who provided key information for this study was a cleaning employee who had worked for 8 years there and according to the guidelines of Duarte (2002), was not only a member of the organization, but also of the Brazilian rabble. The true name of this informant has been substituted in this article by Janaína, an allusion to a character in a song by Biquíni Cavadão, about a worker with dreams, but without the time to realize them.

The relationship between Janaína and the researcher occurred in a similar mode to the relationship between Foot-White (1995) and Doc, his key informant. Just like Doc, Janaína changed the perspective of the researcher in terms of the club employees, and the intimacy and knowledge acquired during the study directly influenced its direction. It should be noted that the citing of the work of Foot-White (1995) is pertinent due to fact that the author counted on only one key informant, but one with singular significance and sensibility, as in this study. While the researcher was in the club gym in the company of Janaína, other employees felt free to talk with the researcher, as if Janaína, due to her presence and time in that locale and the respect she received from her colleagues, were giving her approval. Even though in this article we do not quote other employees besides Janaína, the categories developed here and the directions that this study has followed have been influenced by every look, gesture and phrase of the employees.

This study presents in its structure the concept of social exclusion and then the concept of social inclusion, as well as the dichotomy and even dialectic relationship between these two concepts which are related terms (SAWAIA, 1999; RAWAL, 2008). Then, we will present the results of the study observations, to make an analysis of the forms of exclusion and inclusion of the members of the rabble who work in the club, based on the concepts of inclusive exclusion and exclusionary inclusion. Finally, we present analyses which seek to answer the questions presented.

\section{EXCLUSION/INCLUSION: EXISTING AND POSSIBLE TENSIONS}

Initially in terms of exclusion, the first aspect analyzed is related to the appearance of the term which has a cohesive and ample literature related to its application. To Rawal (2008), the term exclusion is used in various countries to designate different forms of exclusion according to the research object adopted by one or another author.

The second aspect to be analyzed in terms of exclusion is based on the insufficiency of the economic dimension to justify those excluded. According to Martins (1997), Cannan (1997) and Haan (2000), individuals are not excluded for not working, but for being members of countless excluded minorities. 
The third aspect addressed here in terms of exclusion has to do with its use in Brazil, which constitutes the focus of this study. In this last aspect, various authors have presented exclusion as part of the exclusion/inclusion dialectic, in a process which includes individuals in precarious situations and silence in relation to exclusion (MARTINS, 1997; SAWAIA, 1999; VERAS, 1999; NASCIMENTO, 2006). It should be mentioned that this theoretical framework leads us to clarify that the exclusion/inclusion dialectic is seen as something intentional, and is fundamental to the next step of this work which presents observed situations of social exclusion and social inclusion in a systematic manner.

Haan (2000) and Wanderley (1999) state that the term social exclusion was coined in 1974 by Rene Lenoir, then the French Secretary of Social Action. Lenoir associated exclusion with factors such as accelerated and disorganized urbanization, income inequality and the inadaptability and uniformity of the school system. This exclusion was felt by poor and unemployed individuals, whose needs were addressed by institutions created to support them.

However, based on the work observations of these same support institutions, Cannan (1997) and Haan (2000) relate that other groups seeking assistance were also identified, such as those with mental health issues, the elderly and immigrants. According to Rawal (2008) and Aasland and Fløtten (2014), the broadening of the number groups of individuals included in the list of the excluded shows that exclusion occurs due to different factors. In this sense, the authors list exclusion in terms of social orders, economics, culture and politics.

Martins (1997) affirms that there has also been an amplification and transformation of the terms used to describe the groups of the excluded such as poor and marginal people, and that an insufficiency of terms characterizes their ever-growing number. With the increase in the groups of the excluded and the forms of exclusion, this term has come to include different meanings, which range from the "conception of inequality as a result of an individual deficiency or a lack of adaptation to social injustice and exploitation" (SAWAIA, 1999, p. 7).

The increase in excluded groups is attributed by Wanderley (1999) and Nascimento (2006) to the crisis in the social management model. According to the authors, this crisis resulted in the weakening of social protection and the fragmentation of social cohesion during the $19^{\text {th }}$ century. This weakening and fragmentation devalued solidarity and overvalued economic relationships. To Martins (1997) discussions about exclusion often reduce the problem to the result, to the extent that the problem is found within the process. To the author, the term exclusion refers to the movement which pushes the poor and weak away from just and concrete situations, or even expels them from certain social relationships.

In Brazil, Veras (1999) and Safatle (2017) relate that the elimination of any assistance practices for the excluded is strongly related to the neoliberal discourse in the economic sphere, which is based on new forms of social subjection in a movement similar to apartheid between classes. However, Souza (2017) clarifies that the economic discourse is adopted strategically to avoid the advance of discussions of inequality in the social field and its privileges. In this manner, Nascimento (2006) does not subscribe to the hypothesis that one is excluded due to some transgression committed by an individual or his or her group. To the author, exclusion is an external imputation, of the dominant over the dominated, which has its origins in colonial Brazil and the exclusion of Native Americans and blacks by various European peoples.

Veras (1999) and Nascimento (2006) further state that the weakening of social support has repercussions in the following ways: a) it raises barriers to the production of an egalitarian society; and b) it offers the excluded a vast menu of dimensions that generate exclusion. These dimensions range from marital instability and an inadequate family and social life to the inexistent participation in social activities.

According to Honneth (2003), the factors that generate exclusion have turned into systematic dimensions of disrespect. However, according to Veras (1999), people who are excluded socially cannot complain and often do not perceive that they are excluded. This occurs because these people are included in the non-citizen dimension of the capitalist community, or in other words, they are subjects capable of consuming goods and services, but the majority of the time their rights are eliminated by dominant groups (VERAS, 1999; NASCIMENTO, 2006).

In this sense, to Veras (1999) and Debord (1991), the ignorance of their rights and a lack of perception of their exclusion are due to socially shared factors, including the fact that we live in a society of imitation, of reproducibility and vulgarization, rather than a society devoted to creation and dreams. In this manner, that which unknown subjects think they are doing when they consume are moments in vain, a type of counterfeit. This movement shifts the focus of factory workers from their exploitation in that environment, superimposing a consumer society on a production society (MARTINS, 1997). 
Castel (1998) further states that the overvaluation of work, as the main tool of consumption and inclusion, also generates the over-devaluation of non-work. In this scenario, non-work first excludes and then results in a new work model based on the desperation citizens who are members of the rabble and do not have training - workers that subject themselves to any conditions to be included. Bearing in mind that in view of the meritocratic discourse of the middle class, the lack of success of the rabble is due to their own weaknesses and not due to political and social weaknesses, and according to Honneth (2003), these rabble individuals accept flexibility (SENNETT, 1999) as a blessing and are excluded from proper forms of work and included in precarious forms of work (KUENZER, 2002).

According to Martins (1997), speaking of exclusion reduces the problem to the result, to the extent that the problem is found in the process. To the author, the term exclusion is related to the movement which pushes the poor and weak away from just and concrete situations and also social relationships. However, it is not possible to treat exclusion and inclusion in an isolated fashion. They need to be treated as a phenomenon that Sawaia (1999) and Rawal (2008) denominate as the dialectic of inclusion/exclusion, with these terms being related and dependent. To Sawaia (1999), this dialectic is encouraged to present the included as being privileged and well supported and the excluded as marginalized. Often the excluded do not feel excluded, but are deprived, and in this way are included in a category which suffers privation (MARTINS, 1997).

In analyzing the Brazilian situation, we perceive that the rabble is part of the meritocratic discourse of the privileged middle class, which values effort as a way to achieve financial and social recognition (SOUZA, 2017), but is excluded from the fruits of this discourse. To Sawaia (1999) and Maciel and Grillo (2009), this exclusion occurs when the members of the rabble do not achieve the same results as the privileged middle class and is strategically legitimized when the guilt is attributed to rabble members and their supposed lack of will and effort. This movement is described by Veras (1999) as a tension between pushing in and pushing out the same group of people, with the objective of leaving them without any possible counter action.

The use of the term inclusion, when applied to some aspect of the rabble is frequently problematic, given that inclusion is not optional but presented as the best solution for the individual to flee exclusion. This fact is related by Maciel and Grillo (2009) in terms of the inclusion of rabble individuals in a group of uniformed workers, who see in this type of inclusion the only solution to distance themselves from delinquency and police frisks. It is a way to be saved from the condition of the excluded, but it may be related to their participation in an exploited or limited group (RAWAL, 2008).

According to Maciel and Grillo (2009), the rabble sees itself included in a group, even with its life focus being categorized by its consumption capacity and economic development, in a reproduction of the neoliberal thinking of the upper and middle classes. However, dignity is not included, just salary camouflaged by the illusion of inclusion through consumption. This model of thinking is necessary for the reproduction of the ideological and social bases of capitalism (MARTINS, 1978).

This inclusion is also demonstrated by other symbols which go beyond consumption. Jodelet (1999) states that systematic categorization, attributed by the same uniforms, functions and punishments to the groups, makes them develop a notion of inclusion. The author further states that individuals included in the dominant groups have more individual characteristics and exercise individuality, while the dominated groups see themselves as homogeneous and individual characteristics end up being the characteristics of the group.

According to Paugam (1999), the inclusion of the rabble in specific groups, even when there is well-intentioned camouflage, is limited, given that welfare itself seeks to maintain this group of people on the margins. In this manner, we can affirm that the inclusion of the dominated rabble in a given group or category only occurs to facilitate their exclusion. The members of the rabble are dressed in their uniforms of non-consumers to facilitate their identification and surveillance (CELEGUIM and ROESLER, 2009).

Kuenzer (2002) presents the concepts of exclusion and inclusion in an interlinked manner, as elements that are not dissociated, creating the terms inclusive exclusion and exclusionary inclusion. The first term, inclusive exclusion, clarifies that the poor are excluded from a stable work condition to be included in a precarious work condition. Exclusionary inclusion, in turn, represents the process of the inclusion of a portion of the population in technical education, as a way to exclude it from developing critical thinking. We should emphasize that based on a reinterpretation of Kuenzer (2002), these terms will be fundamental to the development of the argument proposed here. 


\title{
EXCLUSIONARY INCLUSION AND INCLUSIVE EXCLUSION: THE EXPERIENCES OF JANAÍNA IN HER WORK AT THE CLUB
}

\author{
Janaína wakes up every day at four thirty \\ And when it's time to go to bed, Janaina thinks \\ That the day isn't over, that nothing has happened [...] \\ But she says \\ That despite everything, she has dreams \\ (Bruno Gouveia, interpreted by Biquini Cavadão)
}

To examine the tensions related to inclusive and exclusive elements of organizational practices, we will seek, in this portion of the study, to evaluate the occasions in which club employees, or the rabble (SOUZA, 2017), experienced systematic situations related to the precarious social category. Based on this finding, the terms inclusive exclusion and exclusionary inclusion (KUENZER, 2002) will be used and (re)interpreted here as a way to explain the phenomena observed in the club's dynamics.

Thus, the situations observed and related in the club are presented as structured forms of legitimization, and the reproduction and maintenance of this social inequality. It is not a problem and is part of social consciousness, justified and institutionally encouraged norms, that the exclusion and inclusion of this precarious social category are experienced and reproduced when it is in the interests of the upper and middle classes.

Janaína felt the exclusion and abandonment of this locale for which she had respect when she entered, but, according to Honneth (2003) it became a symbol of suffering:

Everyone said: 'Wow, you're working in the club,' and I felt a little proud. But after a while, I discovered how it is, and I don't feel valued anymore.

The reports begin with the uniform received by Janaína when she began working at the club, made with cheap fabric and with a used appearance, which is the uniform of the category which occupies the base of the worker hierarchy of that organization - the cleaning employees. This is the first element which includes by excluding. This uniform, even though it represents the inclusion of an individual in the work force, has the objective of excluding these employees from any social interaction with the members or even other employees. This was noted by observations over a 10-minute period, when Janaína remained at the entrance of the pavement and roughly 20 members passed by her, without a single one greeting her, even when they did look at her.

The individual's hiring by the club includes the employee in a uniformed group which is monitored and is part of a group of hard-working individuals. However, the uniforms, camouflaged in the good intention not to wear out the employees' clothes with work and being part of a group (PAUGAM, 1999), function as a way to homogenize individuals. This group, in the eyes of the members and the society which passes through there, is inferior in terms of its consumption capacity and represents disqualified individuals (CELEGUIM and ROESLER, 2009; SOUZA, 2017).

These statements are supported by the fact that not all employees use uniforms within the club. The board of directors, made up of members who occupy strategic positions, does not use a uniform, because these individuals are part of a privileged class and have knowledge (SOUZA, 2017). This board is the dominant group that Jodelet (1999) states has greater individuality, because their functions are exercised using designer clothing. The managers also do not use uniforms, because they are not members of the rabble and are members of the middle class that Souza (2017) classifies as the foremen of the elite. These managers are given privileges by their superiors on the board, such as negotiating which companies can and cannot provide services to the club (FREYRE, 2003; SOUZA, 2017).

The same absence of a uniform which represents status on the strategic and managerial levels, is punished in the case of the rabble. Janaína relates:

[...] these days I was using a different blouse, because it was cold, you know? The club's manager asked if I didn't have a uniform. My supervisor always says that this will still result in a warning. 
And she presents another situation, related to shoes:

I bought better tennis shoes [better ergonimically than those the club offered for work], but they were red. I have back pain from standing all day. They said that they have to be black to match the uniform. And now, if I want another pair, I'll have to buy them.

The back pains related by Janaína we can relate to another social situation: the surveillance of the heavily monitored environment (BENTHAM, 2013) of the club's gym which features 15 cameras with a range of $200 \mathrm{~m}^{2}$. Apparently, there is no other objective for this surveillance than establishing order and placing the unequal coercively in a group of individuals (FOUCAULT, 2003).

This becomes clear when, during the conversations with the researcher, Janaína pretends to be holding cleaning utensils and incessantly cleaning the nearby gym equipment, even though it hasn't been used since the last cleaning. In addition, it reinforces the idea that there should not be social interaction between employees and members. Despite the fact that there is no written rule that prohibits an employee from conversing with a member, in the words of Martins (1999), there is embarrassment in breaking decorum. This embarrassment is found in the habits and social construction of the club, which informally instructs members and employees to avoid any intimacy.

This prohibited intimacy, or, in the words of Martins (1999), the breaking of decorum, is demonstrated in Janaína's report, when she tells us that her supervisor called her attention to a complaint by a member who alleged that she couldn't concentrate because Janaína was conversing with another member.

The surveillance always functions as a way to demonstrate to the employees that working in the club means not resting, even if your work is done. The included, here, are excluded from work routines such as rest or appropriate workdays which benefit productivity. We observed various times that the gym, even though it was empty was being incessantly cleaned by the employees. This behavior is clarified by Janaína's words: "sitting, we really can't do, it's twelve hours standing..." and she affirms that "you have to keep on moving", making it clear that the cleaning employees always need to look like they are cleaning or they will suffer sanctions.

And if Janaína and her peers cannot speak with members, they also probably cannot lunch near them. During our observations, we verified the existence of a locale outside of the club on the other side of the street where the employees went periodically. When questioned about this locale, Janaína related that this is a space called the association, which was initially intended for the employees to socialize, but is used effectively as a cafeteria, dressing room and a place to leave their effects before entering the club. It should be noted that being a member of the association requires a monthly payment by the employees.

We have characterized the rabble as a class derived from slavery, based on the words of Souza (2017), so, it is possible to categorize the association as its slave house. This refers to a locale where social inequality is legitimized, in which the club deposits "white", "black", "brown" and "mulatto" men and women, without distinction of gender or race/ethnicity, but rather as an exclusive distinction of a social race that uses a uniform. In that locale, the employees are excluded from the social space of the club to be included in a group which belongs to the same uniformed class and which eats the same food. We can affirm that the food offered to the employees places them in an even worse condition, since, in the words of Janaína,

\section{[...] the food is horrible; l even bring food from home, because my stomach can't take that food anymore.}

Based on Jodelet (1999) and Celeguim and Roesler (2009), we can state that the categorization of the uniforms and the association initially created, in a symbolic fashion, a notion of inclusion. It should be noted, however, through observations, that it is perceived in the association that all of the relationships experienced within the club are reproduced. There, a place designed for interaction between the employees, the groups do not mix and continue to reproduce the actions of the club, excluding them based on the uniforms they wear.

The club's TVs were another social situation observed in this study. The club has televisions in various places within its structure. These televisions repeat incessantly, as in Orwell's 1984 (2009), commercials for products and services made by club members and present these members as dedicated, hard-working winners who merit their social position. It's a meritocracy in which the excluded class is not heard or felt. 
In this manner, the employees perceive that they are excluded from that group of winners who buy exclusive products and services with the fruit of their efforts. Thus, the employees are part of the category which overvalues work and the blessing of paid work as a way to consume that which is presented in a fake spectacle of consumption (DEBORD, 1991; CASTEL, 1998; VERAS, 1999). These forms of exclusion are structurally thought out to reproduce the ideological and social bases of capitalism (MACIEL and GRILLO, 2009).

Social events promoted by the club (parties and the employee bazaar) or the attitudes of some members, presented below, relate to exclusionary inclusion and this combines with the maintenance of inequality by the welfare mentioned by Paugam (1999).

Once a year, the club closes its doors to members to give employees a day to "enjoy" the club with their families. To Carneiro and Rocha (2009), these parties bring servants to the table as a way to reaffirm that they should always be working. The party occurs under the surveillance of cameras, managers and board members and has a double objective in relation to the maintenance of social inequality: a) the first motive is to relate the success that this individual presents his or her family, a sumptuous environment featuring pools and leisure, and is thus excluded from an almost certain fate of delinquency; and b) the second motive is related with the first and what Maciel and Grillo (2009) affirm occurs among the members of the rabble who are employees, that in taking their children to the party they see their parent's work and are already familiarized with their futures, their only opportunities which will consist of being servants to the middle class.

The employee bazaar also calls our attention to the extent that the club encourages the members to donate clothes, utensils, and appliances set up so that the employees can choose items that are no longer of use to the club members. Carneiro and Rocha (2009) understand this type of event's purpose as being to diminish the rabble's desire to have a member's life, given that they already have a small piece of it.

This little piece of a member's life which should satiate the appetite of the rabble is also demonstrated in Janaína's words, when she reports that with her efforts, she has managed to buy a two-story house in the metropolitan region of the capital where the club is located, in one of the state's most violent regions, but which "is in a closed condominium and has a barbeque". These details she emphasized more than once in various conversations, because this, to her, brings her closer to those she serves.

We also can observe symbolically the inclusion of employees in the category of the "toy companions", mentioned by Freyre (2003, p. 149). In the author's reports, buffoons and their wives dominate and treat their servants as they like, with a certain cruelty. In the same way, the members, when they feel alone on their treadmills or need to inflate their egos, call over the physical education interns or an employee who's nearby. Knowing that it is a breaking of decorum to ignore the attentions of a member, the employees are included in a conversation. The inclusion in the conversation, which may be about the member's trips, purchases or achievements, excludes the employee from an economic and social capacity. It is not rare, for the same members, after their sumptuous reports, to ask the employees or interns for a cup of water.

Finally, the last situation observed was when Janaína told us, with tears in her eyes, that she had resigned from the club, because she had a panic attack upon seeing a female member who "was always criticizing her" come up to the place where she was cleaning. However, the humiliation did not stop even when she decided to leave the club. We can observe in this case what Honneth $(2003$, p. 217) terms "a denial of the current social legal pretensions" of the excluded individual, which causes a loss of self-respect. Janaína spent three days going to work with anxiety and nervousness, going between the human resources department and the floors which should have been cleaned, waiting for the manager to have the time to respond whether the club would accept her resignation.

This last related situation was treated as a "final blow" applied to Janaína by the club. As if all the suffering and humiliation, conscious and unconscious, that she went through during her last days at work after resigning were not enough, which are usually days in which the individual feels relief after making this decision, she went through more suffering which involved stress and uncertainties. This is a demonstration that it was not the club which excluded or included her in situations which were convenient to it, but rather all of society, which is determined not by the hegemony which she serves, but that which she does not serve. 


\section{FINAL CONSIDERATIONS: A STRUCTURED PROJECT OF SOCIAL INEQUALITY?}

The observation and presentation of the situations experienced by the club employees serve to demonstrate that they do not occur by chance, but constitute a project to maintain and amplify social inequality. In the introduction of this article we made it clear that the employees are considered part of the rabble, according to the classification of Souza (2009). We also used the existing tension between the movements of exclusion and inclusion to show that this is not simply pure social exclusion, which has been reduced to poverty at other times (RAWAL, 2008; AASLAND and FL $\varnothing T T E N, 2014)$. There is also here the inclusion which marks an individual within a group which is excluded in various ways, in terms of cultural and educational rights, but which is necessary to maintain certain social structures.

In a club frequented by the foremen of the elite (SOUZA, 2017) and located in the southern region of Brazil, an employee who obtains an operational position also believes he or she is accessing a project of social inclusion and feels part of the club. In the vision of Sennett (1999), Kuenzer (2002) and Maciel and Grillo (2009), this is a project which attracts an individual member of the rabble, who is divided between the possibility of delinquency and the entrance into formal salaried, but precarious, work. The authors argue that the work is precarious because the flexible shifts offered are interesting only to the employer, and the employee is treated like an easily substituted object. This is inclusion which appears to be purely positive, but does not reveal its exclusionary side.

Based on this entrance, which is not so inclusive, these individuals experience a series of situations which include and exclude them. Initially the employee receives a uniform which will mark even more who that person is within this social environment. And this is not related to poverty, corroborating the initial concept of social exclusion (RAWAL, 2008; AASLAND and FL ØTTEN, 2014), given that Janaína, even though she is the lowest employee category in the club, has her own home in a closed condominium as well as a motorcycle. Honest and hard-working, Janaína is systematically victimized by social and physical exclusion when she has lunch, by the exclusion of dignity when no one greets her for 12 hours, and the exclusion of her rights when she has to remain standing for 12 hours, remaining under observation, and not even being able to leave when she resigns (HONNETH, 2003).

We have also presented the uniform as evidence of the structured form of exclusionary inclusion, given that the subject who is a member of the rabble is included in a condition which will enable this person to avoid frequent police frisks (MACIEL and GRILLO, 2009), but is also marked as a non-consumer of good products and services, as affirmed by Celeguim and Roesler (2009) and Souza (2017). The relationship between employees who use a uniform and those who do not is structured to legitimize the social hierarchy and inequality between the groups. This inequality is also reproduced by the employees themselves and the members of the rabble, who lower their heads when a club member passes, and the club members who only greet employees with clothes similar to theirs - the foremen of the elite.

The tension between exclusion and inclusion can also be identified in events as well as the functioning of televisions in the club, when exclusive products and services are presented to deserving club members, but observed repeatedly by members of the rabble. It is during these moments that legitimization occurs, in terms of the meritocracy of the middle class and its achievements when compared to the failure of the rabble (SOUZA, 2017). After spending twelve hours observing goods and services, as well as the access to them being achieved through effort and dedication, the employees have no other option than working without sitting or complaining, to achieve all of this. In this case, the employee is excluded from the capacity to consume, but is included in a situation which thinks that this is positive, because the person is working. Thus, this inclusion in precarious work excludes workers from the chance to acquire these goods, making them include themselves in a group which is perceived as a failure.

In this manner, we believe that the question which led to this study can be answered by symbols, the ways and tools that the middle class uses to systematically maintain and amplify social inequality. These resources, in turn, extend to various forms of social exclusion and inclusion, concepts which have been found in this study to be umbilically linked. We also believe that the use of the concepts proposed by Kuenzer (2002) are appropriate to this empirical case and enrich the understanding of movements realized and strategically structured by the middle class to distance themselves from the rabble and move closer to the elite which presents this illusionary vision.

To not leave any loose ends, we conclude by affirming that a while later, Janaína's resignation was finally accepted by the club, and the daughter's "stolen" boot mentioned at the outset, was actually hidden by her friends. Everyone laughed after perceiving this prank, without even glancing at the security guard who returned to his post in silence. He was excluded from the prank, but included in a possible robbery by the foremen of the elite. 


\section{REFERENCES}

AASLAND, A.; FL ØTTEN, T. Ethnicity and social exclusion in Estonia and Latvia. Europe-Asia Studies, v. 53, n. 7, p. 1023-1049, 2014.

BENTHAM, J. O panóptico. 2. ed. Belo Horizonte: Autêntica, 2013.

BENTO, J. A. N. et al. Avaliação multidimensional da exclusão social em áreas rurais. Revista Ciências Administrativas, v. 22, n. 1, p. 306-331, 2016.

BOERE, N.; LIMA, L. Placa em banheiro do Country Club informa que babás não podem entrar. O Globo, Rio de Janeiro, 25 jun. 2016. Available at: <https://oglobo.globo.com/rio/placa-em-banheiro-docountry-club-informa-que-babas-nao-podem-entrar-19372359>. Accessed on: Dec. 16, 2018.

CANNAN, C. The struggle against social exclusion: urban social development in France. IDS Bulletin, v. 28, n. 2, p. 77-85, 1997.

CARNEIRO, M. T.; ROCHA, E. Do fundo do buraco: o drama social das empregadas domésticas. In: SOUZA, J. (Org.). A ralé brasileira: quem é e como vive. Belo Horizonte: Ed. UFMG, 2009. p. 125-142.

CARVALHO-FREITAS, M. N.; MARQUES, A. L. Formas de ver pessoas com deficiência: um estudo empírico do construto de concepções de deficiência em situações de trabalho. Revista de Administração Mackenzie, v. 11, n. 3, p. 100-129, 2010.

CASTEL, R. As metamorfoses da questão social: uma crônica do salário. Petrópolis: Vozes, 1998.

CELEGUIM, C. R. J.; ROESLER, H. M. K. N. A invisibilidade social no âmbito do trabalho. Interação: Revista Científica da Faculdade das Américas, v. 3, n. 1, p. 1-19, 2009.

DEBORD, G. A sociedade do espetáculo. Lisboa: Mobilis in Mobile, 1991.

DJELIC, M. History of management: what is the future for research on the past? In: CZARNIAWSKA, B. (Ed.). A research agenda for management and organization studies. Cheltenham: Edward Elgar, 2016. p. 1-10.

DUARTE, R. Pesquisa qualitativa: reflexões sobre o trabalho de campo. Cadernos de Pesquisa, n. 115, p. 139-154, 2002.

FOOTE-WHYTE, W. Treinando a observação participante. In: GUIMARÃES, A. Z. Desvendando máscaras sociais. Rio de Janeiro: Forense, 1995. p. 77-86.

FOUCAULT, M. Vigiar e punir. 29. ed. Petrópolis: Vozes, 2003.

FREITAS, L.; LUNA, L. A família desorganizada e a reprodução da "ralé estrutural" no Brasil. In: SOUZA, J. (Org.). A invisibilidade da desigualdade brasileira. Belo Horizonte: Ed. UFMG, 2006. p. 323-358.

FREYRE, G. Casa-grande \& senzala: formação da família brasileira sob o regime de economia patriarcal. 48. ed. Recife: Global, 2003.

GONÇALVES, R G. et al. Instrumentos de Planejamento: a interferência nas paisagens urbanas e a exclusão social. Revista Reuna, v. 14, n. 3, 2009.

HAAN, A. Social exclusion: enriching the understanding of deprivation. Studies in social and political thought, v. 2, n. 2 , p. 22-40, 2000.
HONNETH, A. Luta por reconhecimento: a gramática moral dos conflitos sociais. São Paulo: Ed. 34, 2003.

JODELET, D. Os processos psicossociais da exclusão. In: SAWAIA, B. (Org.). As artimanhas da exclusão. Petrópolis: Vozes, 1999. p. 53-66.

KUENZER, A. Z. Exclusão includente e inclusão excludente: a nova forma de dualidade estrutural que objetiva as novas relações entre educação e trabalho. Capitalismo, Trabalho e Educação, v. 3, p. 77-96, 2002.

MACIEL, F.; GRILLO, A. O trabalho que (in)dignifica o homem. In: SOUZA, J. (Org.). A ralé brasileira: quem é e como vive. Belo Horizonte: Ed. UFMG, 2009. p. 241-280.

MARTÍN, M. O dia a dia de uma babá entre a elite do Rio de Janeiro. Pragmatismo Político, João Pessoa, June 03, 2016. Available at: <https://www.pragmatismopolitico.com.br/2016/06/o-dia-a-diade-uma-baba-entre-a-elite-do-rio-de-janeiro.html>. Accessed on: Dec. 16, 2018.

MARTINS, J. S. Sobre o modo capitalista de pensar. 4. ed. São Paulo: Hucitec, 1978.

MARTINS, J. S. Exclusão social e a nova desigualdade. São Paulo: Paulus, 1997.

MARTINS, J. S. Vergonha e decoro na vida cotidiana da metrópole. São Paulo: Hucitec, 1999.

MATITZ, Q. R. S.; VIZEU, F. Construção e uso de conceitos em estudos organizacionais: por uma perspectiva social e histórica. Revista de Administração Pública, Rio de Janeiro, v. 46, n. 2, p. 577-598, 2012.

MEDEIROS, L. F. R.; MACÊDO, K. B. Catador de material reciclável: uma profissão para além da sobrevivência? Psicologia \& Sociedade, v. 18, n. 2, p. 62-71, 2006.

NASCIMENTO, E. P. Hipóteses sobre a nova exclusão social: dos excluídos necessários aos excluídos desnecessários. Caderno CRH, v. 7, n. 21, p. 29-47, 2006.

ORWELL, G. 1984. São Paulo: Companhia das Letras, 2009.

PAULA, A. P. P. et al. A tradição e a autonomia dos estudos organizacionais críticos no Brasil. Revista de Administração de Empresas, v. 50, n. 1, p. 10-23, 2010.

PAUGAM, S. O enfraquecimento e a ruptura dos vínculos sociais. In: SAWAIA, B. (Org.). As artimanhas da exclusão. Petrópolis: Vozes, 1999. p. 67-86.

RAWAL, N. Social inclusion and exclusion: a review. Dhaulagiri Journal of Sociology and Anthropology, v. 2, p. 161-180, 2008.

SAFATLE, V. Só mais um esforço. São Paulo: Três Estrelas, 2017.

SAWAIA, B. (Org.). As artimanhas da exclusão. Petrópolis: Vozes, 1999.

SENNETT, R. A corrosão do caráter. Rio de Janeiro: Record, 1999.

SILVA, D. A.; LIMA, R. A.; NELSON, A. V. M. Exclusão social, ocupação urbana e moradia à luz do princípio da função social das cidades. Interface: Revista do Centro de Ciências Sociais Aplicadas, v. 13, n. 2, p. 129-144, 2016. 
SOUZA, J. (Org.). A ralé brasileira: quem é e como vive. Belo Horizonte: Ed. UFMG, 2009.

SOUZA, J. A elite do atraso: da escravidão à Lava Jato. Rio de Janeiro: Leya, 2017.

SPRADLEY, J. P. The ethnographic interview. Long Grove, IL: Waveland, 2016.
VERAS, M. Exclusão social: um problema brasileiro de 500 anos. In: SAWAIA, B. (Org.). As artimanhas da exclusão: análise psicossocial e ética da desigualdade social. Petrópolis: Vozes, 1999. p. 27-52.

WANDERLEY, M. B. Refletindo sobre a noção de exclusão. In: SAWAIA, B. (Org.). As artimanhas da exclusão. Petrópolis: Vozes, 1999. p. 16-26.

Fernando Ressetti Pinheiro Marques Vianna

ORCID: https://orcid.org/0000-0002-5698-477X

Ph.D. Student in Business Administration at the São Paulo School of Business Administration of Getulio Vargas Foundation (FGV EAESP); Master's in Administration from Federal Technological University of Paraná (UTFPR), Curitiba - PR, Brazil. E-mail: fvianna2009@hotmail.com

Francis Kanashiro Meneghetti

ORCID: https://orcid.org/0000-0003-0327-2872

Ph.D. in Education; Professor at Federal Technological University of Paraná (UTFPR), Curitiba - PR, Brazil. E-mail: fkmeneghetti@gmail.com

Juliana Previatto Baltini Tonon

ORCID: https://orcid.org/0000-0002-7975-8003

Master's in Administration; Professor at Faculty of Social and Applied Sciences of Paraná (FACET), Curitiba - PR, Brazil. E-mail: julianabaldini@yahoo.com.br

Ph.D. in Administration; Professor at Federal Technological University of Paraná (UTFPR), Curitiba - PR, Brazil. E-mail: leonardotonon@utfpr.edu.br 